\title{
Advanced Manufacturing Engineering Technology Program: a Program that Prepares Graduates for Today's Manufacturing Industry
}

\section{Dr. Hossein Rahemi, Vaughn College of Aeronautics \& Technology}

Dr. Hossein Rahemi is a professor and department chair of Engineering and Technology at Vaughn College of Aeronautics \& Technology. He is the author of two books, Vaughn College Journal of Engineering and Technology (VCJET), numerous conference papers in the areas of solid mechanics, computational mechanics, vibration analysis, fracture mechanics and reliability analysis. He is also a principle investigator for the NSF S-STEM grant and the HIS-STEM grant and a student adviser for a number of technical papers in the areas of mechanics, robotics and industrial automation.

\section{Prof. Amir Elzawawy , Vaughn College of Aeronautics \& Technology}

Dr. Amir Elzawawy is an assistant professor at Vaughn College of Aeronautics and Technology. Dr. Elzawawy teaches courses in mechanical and mechatronic engineering and engineering technology programs. His research background is in the area of experimental fluid mechanics and currently active on the area of CFD (Computational Fluid Dynamics) and heat transfer simulations. This in addition to developing STEM programs to enhance engineering education experiences focused on improving retention and graduation rate.

Dr. Yougashwar Budhoo, Vaughn College of Aeronautics and Technology 


\title{
Advanced Manufacturing Engineering Technology Program-A program that prepares graduates for today's manufacturing industry
}

\begin{abstract}
This paper details the development process of a new Advanced Manufacturing concentration within a mechanical engineering technology program at a college in the Northeastern Region of the United States. The development and implementation process of this program is supported by the department of education federal fund as part of Title III, Part F, HSI-STEM and Articulation grant.

Today, manufacturing is in high demand in aeronautical and other technical fields for a wide range of tasks, such as Computer Numerical Control machining, computer-aided design \& 3D prototyping, composite structural design \& repair, robotics, and unmanned aerial vehicles (UAV) to name a few. Given these demands, this program is designed to provide students with the practical hands-on manufacturing skills needed in aeronautical and related technical fields.

Graduates of this program will acquire knowledge in the area of Computer-Aided Design and 3D Printing, Computer-Aided Manufacturing and Prismatic Machining, Composite Manufacturing and repair process, CATIA Composite Product Design, and UAV applications covering a wide range (business, scientific, and security). Students in this field are required to take courses in basic engineering sciences and application (applied statics \& strength of materials, applied thermos-fluid, and mechanical testing) to further enhance their understanding in aeronautical manufacturing process and design. Two credit hours of technical elective course work provide students with opportunities to choose from elective courses to specialize in the area of 3D prototyping, composite inspection and repair, or UAV and its application. To complete this program, students are required to take 3 credit hours of a senior manufacturing capstone project.
\end{abstract}

The goal of the engineering and technology department for developing this program is to provide our students with hands-on and manufacturing skills that are current with today's industry trends. The main objective is to provide students with strong foundation in composite manufacturing, computer-aided manufacturing \& 3D printing, Computer Numerical Control manufacturing, and UAV construction and application. A concurrent program objective is to provide students with the knowledge, experience and ability to evaluate these approaches for their use in applicable situations.

The development and implementation of the Advanced Manufacturing program, including the program's evaluation survey by the manufacturing industry, will be discussed in detail at the ASEE Annual Conference. 


\section{Introduction}

The new Advanced Manufacturing program will provide an additional concentration to the existing Mechanical Engineering Technology program through the provision of practical handson manufacturing skills in related aeronautical and technical fields.

In addition to the required mechanical engineering technology courses, this program will include a practical manufacturing course in four concentrations: Composite Design \& Manufacturing, Computer Aided Design for Additive and Subtractive Manufacturing, Computer Numerical Control (CNC) Manufacturing, and UAS Design, Construction, and Application. A total of 128 credits will be required: 61 in liberal arts and math and science courses, and 67 technical courses in both mechanical engineering technology and hands-on manufacturing courses.

The primary mission of the engineering and technology department is to provide students with a high quality and practical advanced manufacturing education that enable them to excel both in their professional careers and in their continued education. The educational mission of the program can thus be summarized as follows:

- Provide students with a strong foundation in Computer-Aided Design and ComputerAided Manufacturing.

- Provide students with a strong foundation in composite manufacturing, inspection, and repair.

- Provide student with a strong foundation in understanding UAS design process, capabilities and its application for a wide range of uses (business, scientific, and security).

- Provide students with knowledge and experience in analytical, programming, and manufacturing methods, and the ability to evaluate these approaches for use in a given practical situation.

- Provide student with both the knowledge and the practical hands-on manufacturing skills that enable them to obtain a position in aeronautical and related manufacturing industries.

Exposing students to both theory and hands-on technical manufacturing projects further enhances their understanding and prepares them for future challenges and for innovations in the manufacturing field. 


\section{BS in Mechanical Engineering Technology Advanced Manufacturing Concentration}

This concentration will be a new addition to our existing mechanical engineering technology program. To complete this degree students are required to take a total of 128 credits, 61 credits are in liberal arts and math and science courses and 67 credits in technical courses focusing on content involving Mechanical Engineering Science \& Technology, Computer-Aided Design, Computer-Aided Manufacturing, Composite Structural Manufacturing, Inspection \& Repair, CNC Machining and Manufacturing, and UAS design, application, and regulation. Table 1 provides breakdown of technical content of this program.

Table1: Technical Content of Advanced Manufacturing Concentration

\begin{tabular}{|l|c|}
\hline Technical Content & $\begin{array}{l}\text { Total number } \\
\text { of credits }\end{array}$ \\
\hline Engineering Science and Application & 38 \\
\hline Computer-Aided Design and Additive Manufacturing & 6 \\
\hline Composite Design, Manufacturing, Inspection \& Repair & 8 \\
\hline CNC Machining and Manufacturing & 6 \\
\hline UAV Construction and application & 4 \\
\hline Technical Electives & 2 \\
\hline Capstone Degree Project & 3 \\
\hline Total & $\mathbf{6 7}$ \\
\hline
\end{tabular}

Table 2 provides a list of Advanced Manufacturing practical courses focusing on content involving Computer-Aided Design, Computer-Aided Manufacturing, Composite Structural Manufacturing, Inspection \& Repair, CNC Machining and Manufacturing, and UAS design and application.

Table 2: Practical Hands-on Manufacturing Courses

\begin{tabular}{|c|c|c|c|c|c|}
\hline $\begin{array}{l}\text { Subject \& } \\
\text { Course }\end{array}$ & Course Name & $\begin{array}{l}\text { Lecture } \\
\text { Credits }\end{array}$ & $\begin{array}{l}\text { Lab } \\
\text { Credits }\end{array}$ & $\begin{array}{l}\text { Total } \\
\text { Credits }\end{array}$ & Prerequisites \\
\hline \multicolumn{6}{|c|}{ Computer-Aided Design and Additive Manufacturing } \\
\hline CDE117 & CAD-I (SolidWorks) & 1 & 1 & 2 & \\
\hline CDE375 & $\begin{array}{l}\text { Computer Graphics for } \text { Additive } \\
\text { Manufacturing }\end{array}$ & 1 & 1 & 2 & \\
\hline CDE385 & CATIA-I & 1 & 1 & 2 & CDE117 \\
\hline \multicolumn{6}{|c|}{ Composite Design, Manufacturing, Inspection \& Repair } \\
\hline AMT202 & Intro to Composite Materials & 3 & 0 & 3 & $\begin{array}{l}\text { MAT120 } \\
\text { EGR235 }\end{array}$ \\
\hline AMT212 & Intro to Composite Manufacturing I & & 1 & 1 & AMT202 \\
\hline AMT312 & $\begin{array}{l}\text { Mold Fabrication and Adhesive Bonding } \\
\text { of Composite and Metals }\end{array}$ & 1 & 1 & 2 & AMT202 \\
\hline AMT402 & $\begin{array}{l}\text { Non Destructive Testing Techniques for } \\
\text { Composite Materials }\end{array}$ & 1 & 1 & 2 & AMT202 \\
\hline \multicolumn{6}{|c|}{ CNC Machining and Manufacturing } \\
\hline AMT201 & CNC Machining and Manufacturing I & 1 & 1 & 2 & CDE117 \\
\hline
\end{tabular}




\begin{tabular}{|l|l|l|l|l|l|}
\hline CDE487 & CAM and Prismatic Machining & 1 & 1 & 2 & CDE385 \\
\hline AMT301 & CNC Machining and Manufacturing II & 1 & 1 & 2 & $\begin{array}{l}\text { AMT201 } \\
\text { CDE385 }\end{array}$ \\
\hline UAS Design and Application & 1 & 1 & 2 & $\begin{array}{l}\text { MAT445 } \\
\text { EGR215 }\end{array}$ \\
\hline AMT321 & UAV-Flying Robots & 1 & 1 & 2 & AMT321 \\
\hline AMT411 & $\begin{array}{l}\text { Quadcopters-UAV Design, Additive } \\
\text { Manufacturing, and Application }\end{array}$ & 1 & 1 & 2 & \\
\hline Select One Tech Elective, 2 credits & $\begin{array}{l}\text { Advanced Composites Drawing and } \\
\text { Interpretation }\end{array}$ & 1 & 1 & 2 & \\
\hline AMT403 & CATIA for Composite Manufacturing & 1 & 1 & 2 & \\
\hline CDE490 & 2 & \multicolumn{3}{|l|}{$\mathbf{2 6}$} \\
\hline AMT401 & Internship \\
\hline
\end{tabular}

Table 3 provides a list of engineering science course within advanced manufacturing engineering technology program.

Table 2: Engineering Science Courses

\begin{tabular}{|l|l|l|l|l|l|}
\hline Engineering Science and Application & 2 & 1 & 3 & \\
\hline EET115 & DC Circuits & 3 & & 3 & $\begin{array}{l}\text { MAT115 } \\
\text { PHY120 }\end{array}$ \\
\hline EGR115 & Engineering Mechanics I & 3 & & 3 & $\begin{array}{l}\text { MAT115 } \\
\text { PHY120 }\end{array}$ \\
\hline EGR235 & Material Science and Composites & 3 & & 3 & $\begin{array}{l}\text { MAT120 } \\
\text { PHY120 }\end{array}$ \\
\hline EGR210 & Thermodynamics & 3 & & 3 & $\begin{array}{l}\text { EGR115 } \\
\text { MAT120 }\end{array}$ \\
\hline EGR220 & Strength of Material I & & & 3 & $\begin{array}{l}\text { EGR115 } \\
\text { MAT120 } \\
\text { PHY220 }\end{array}$ \\
\hline EGR215 & Engineering Mechanics II & 3 & & & EGR210 \\
\hline EGR260 & Aerodynamics I & 3 & 3 & $\begin{array}{l}\text { EGR220 } \\
\text { MAT220 }\end{array}$ \\
\hline EGR225 & Strength of Material II & 3 & & 3 & $\begin{array}{l}\text { MAT220 } \\
\text { EGR210 }\end{array}$ \\
\hline EGR345 & Fluid Mechanics & 3 & & 3 & EGR235 \\
\hline EGR230 & Mechanical Testing and Evaluation Lab & & 1 & 1 & $\begin{array}{l}\text { MAT220 } \\
\text { EGR220 }\end{array}$ \\
\hline EGR340 & Computational Methods in Engineering & 3 & & 3 & $\begin{array}{l}\text { EGR210 } \\
\text { MAT220 }\end{array}$ \\
\hline EGR440 & Heat Transfer & 3 & 3 & $\begin{array}{l}\text { EGR210 } \\
\text { EGR345 }\end{array}$ \\
\hline EGR375 & Thermo-Fluid Lab & & 3 & $\begin{array}{l}\text { EGR225 } \\
\text { EGR215 }\end{array}$ \\
\hline EGR365 & $\begin{array}{l}\text { Elements of Machine Design and } \\
\text { Kinematics }\end{array}$ & 3 & & 3 & \\
\hline
\end{tabular}




\subsection{Curriculum Evaluation by Industry Advisory Members}

The Manufacturing industry advisory members play a pivotal role in program development, implementation and students' success. The industry advisory members work closely with faculty members of the engineering and technology department in developing new certificates; new course offerings and development of overall manufacturing curriculum. They reviewed the manufacturing program proposal and provided their valuable feedback and input related to new course offerings, laboratory contents and hands-on skills to prepare students for the manufacturing industries. This group is selected among local and national manufacturing industries (Pavon Manufacturing Group, Composite Prototyping Center, Dassault Systèmes, FormLabs, SciMax Technologies, Cyient, Corning, ADDAPT, and Sikorsky) with background in $\mathrm{CNC}$ machining and manufacturing, Computer Aided-Design and Aided Manufacturing, 3D printing and additive manufacturing, Composite design, manufacturing, and repair, as well as aeronautical manufacturing. For past several years, they provided our students and graduates with both internship and employment opportunities. .

The proposal for this advanced manufacturing program, as well as a feedback evaluation survey, was distributed to our industry advisory members during College's Ninth Annual Technology Day conference on April 27, 2017 [1] as well as during College's third Annual Manufacturing Day conference on Oct 27, 2017 [2] and the table below shows the results of their evaluations.

Table 2: Survey's Result and Analysis

\begin{tabular}{|c|c|c|c|c|}
\hline \multirow[t]{2}{*}{ Questions } & \multicolumn{4}{|c|}{$\begin{array}{l}\text { Response in percent of participants } \\
\text { (Number of participants: } 6 \text { ) }\end{array}$} \\
\hline & $\begin{array}{c}\text { Poor } \\
1\end{array}$ & $\begin{array}{c}\text { Fair } \\
2\end{array}$ & $\begin{array}{c}\text { Good } \\
3\end{array}$ & $\begin{array}{c}\text { Excellent } \\
4\end{array}$ \\
\hline $\begin{array}{l}\text { 1. How would you Rate this program in providing graduates with } \\
\text { Computer-Aided Design, Computer-Aided Manufacturing and 3D } \\
\text { Printing skills? }\end{array}$ & & & & 6 \\
\hline $\begin{array}{l}\text { 2. How would you Rate this program in providing graduates with } \\
\text { skills in Composite Manufacturing, Design, Inspection, and Repair? }\end{array}$ & & & 2 & 4 \\
\hline $\begin{array}{l}\text { 3. How would you rate this program in providing graduates with } \\
\text { skills in Computer Numerical Control (CNC) machining and } \\
\text { manufacturing process? }\end{array}$ & & & 1 & 5 \\
\hline $\begin{array}{l}\text { 4. How would you rate this program in providing graduates with } \\
\text { skills in UAV design, construction and application? }\end{array}$ & & & 2 & 4 \\
\hline $\begin{array}{l}\text { 5. How would you rate this program in preparing graduates for the } \\
\text { manufacturing career? }\end{array}$ & & & 2 & 4 \\
\hline $\begin{array}{l}\text { 6. How would you rate this program of study in preparing graduates } \\
\text { with adequate knowledge and skills for professional practice? }\end{array}$ & & & 3 & 3 \\
\hline $\begin{array}{l}\text { 7. How would you rate this program for preparing graduates to } \\
\text { pursue graduate study and or professional education? }\end{array}$ & & & 2 & 4 \\
\hline $\begin{array}{l}\text { 8. Professor's ability in introducing you to technical writing and } \\
\text { presentation }\end{array}$ & & & 2 & 5 \\
\hline $\begin{array}{l}\text { 9. Rate SEE program in providing you with skills in problem } \\
\text { solving, communication, and teamwork. }\end{array}$ & & & 1 & 6 \\
\hline Overall Rating & & & $27 \%$ & $73 \%$ \\
\hline
\end{tabular}


Analysis: Overall, 73 percent of the survey participants rated the advanced manufacturing program as excellent and 27 percent rated it as good. The industry advisory survey results are an indication that the program content provides graduates with the knowledge and skills necessary to remain current with the trends in today's manufacturing industry.

Also, below are some advisory members' responses to two questions on the evaluation survey regarding the advanced manufacturing program:

1. Upon reviewing the proposal of the Advanced Manufacturing Program, what qualities in the curriculum do you find are the most favorable? Please share your comments in the provided space.

\section{Responses}

$>$ I feel this program has a good mixture of fundamental, theory, applied engineering, and hands on classes. I believe it is not only imperative for student to have a strong foundation on theories, but also knows when and where to apply them. The curriculum includes fabrication, evaluation, manufacturing, testing classes/labs which I feel is very keying in today's world. I think this curriculum will proper prepare the students for this industry.

$>$ Generally, the technical courses appear to be addressing the required knowledge necessary for a graduate to progress in this discipline and more importantly prepare them to grow and develop those skills in the professional work environment.

$>$ The Consideration of both composite material and metals for machining will add great value for students both short and long term. The overlap between programming and $\mathrm{CNC}$ will also be beneficial.

$>$ The hands-on components provided in the lab courses that make the theory taught practical and it will make student marketable in manufacturing industries.

2. Would your organization be interested in a graduate with both manufacturing and engineering technology skills? Please share your comments in the provided space. Responses:

$>$ Absolutely, our organization would be interested in a graduate with both manufacturing and engineering technology skills. The more well-rounded the student, the better they will be in dealing with various engineering issues.

$>$ My company is always looking for talents in engineering technology field.

$>$ Yes, my organization is interested in graduates with manufacturing and engineering technology skills.

\subsection{Assessment Plan}

The College is dedicated to providing a distinctive education to a diverse population of students. Our mission is to provide a dynamic learning environment built on our aeronautical heritage that inspires a diverse and committed community of students to achieve success as leaders in the industries we serve. Consistent with the mission of College and the input from our constituencies (industrial advisory council, alumni, student and employer surveys), engineering and technology faculty members have drafted and updated a set of program educational objectives (PEOs) which provide students with a career-oriented education, support application-oriented research, and offer service in the public interest. Also consistent with this mission, the primary goal of the engineering and technology department is to 
produce a skilled graduate capable of growth within the industry, who is prepared to pursue continuing education, and who will thus contribute to the economic development of the country. These program objectives are intended to produce versatile engineers and technicians who:

1. Will be successful and excel in their chosen career path. Graduates of this program will be able to obtain positions that require manufacturing knowledge and skills that are current with today's industry trends.

2. Will be able to pursue engineering and professional education.

3. Conduct themselves as responsible members of society through involvement in the community and through their professional engagement.

As a direct measure, courses offered through the program and employer surveys are used to assess the effectiveness of program objectives in attaining student outcomes. The following learning outcomes based on the ABET criteria 3 (ABET- ETAC, 2018-2019) [3] have been established to assess the student learning in this program. These student outcomes are as follows:

a) Graduates will demonstrate an ability to apply the knowledge, techniques, skills, and modern tools used in manufacturing engineering technology program.

b) Graduates will demonstrate an ability to apply knowledge of mathematics, science, and engineering principles to analysis and design.

c) Graduates will demonstrate an ability to conduct standard tests and measurements; to conduct, analyze, and interpret experiments; and to apply experimental results to improve manufacturing processes.

d) Graduates will demonstrate an ability to design and manufacture engineering systems and components.

e) Graduates, through group manufacturing projects and presentation, will gain the broad education necessary to function effectively as a member of a technical team

f) Graduates will demonstrate an ability to identify, formulate, and solve problems related to manufacturing engineering technology program.

g) Graduates of advanced manufacturing will be able to communicate effectively through oral presentation, writing and graphic communication

h) Graduates of advanced manufacturing will demonstrate an understanding of the need for and an ability to engage in self-directed continuing professional development.

i) Graduates of advanced manufacturing will demonstrate an understanding of professional and ethical responsibility including a respect for diversity.

j) Graduates of advanced manufacturing will develop the broad education necessary to understand the impact of engineering technology solutions in a global, economic, environmental, and societal context

k) Graduates of advanced manufacturing will demonstrate recognition of the need for quality, timeliness, and continuous improvement.

As a direct measure, courses offered through the program and employer surveys are used to assess the attainment of student learning outcomes. The Faculty Course Assessment Report (FCAR) will be implemented to assess the attainment of student learning outcomes through 
assigned course tasks. As an indirect measure, the department exit survey, the alumni survey, and the internship supervisor surveys are used in the assessment process of student learning outcomes. The effectiveness of learning outcomes and program educational objectives based on the results of FCARs and collected surveys will be analyzed in program level, and for any shortcoming that is identified, a proper action plan for improvement will be implemented [4].

\section{Manufacturing Certificate Programs}

Besides developing a curriculum in advanced manufacturing, the Engineering and Technology department is developing several stackable manufacturing certificate programs in Composite Design \& Manufacturing, 3D Additive and Subtractive Manufacturing, CNC Machining and Programming, UAS Design and Application. The main objective of developing these certificate programs is to provide graduates with the knowledge and practical manufacturing skills current with today's manufacturing trend as well as to enhance their career opportunities with regional and national manufacturing industries. Many of the practical certificate courses are part of advanced manufacturing curriculum, and hence graduates of these certificate programs have an opportunity to continue their education and to obtain a BS degree in advanced manufacturing as well.

\subsection{Composite Design and Manufacturing Certificate Program}

This certificate program provides a "well-rounded" education to prospective engineers and technicians who are interested in composite materials and its manufacturing process and application. Students will be introduced to the analysis of composite materials along with hands-on experience in composite manufacturing. Students will also be introduced to mold fabrication and adhesive bonding of composite and metals, which is an integral part of composite manufacturing. Finally, students will be exposed to the most common and latest Non-Destructive Inspection (NDI) equipment, methods and techniques used in the field of composite inspection. This is a one year certificate program and a total of five practical composite design and manufacturing courses (12 credits) as listed below will be required to complete this certificate program.

$>$ AMT101: Introduction to Engineering Materials (3 credits, 3 lecture hours) Semester I

> AMT202: Introduction to Composite Materials (3 credits, 3 lecture hours) Semester I

$>$ AMT212: Introduction to Composite Manufacturing (2 credits, 1 lecture hour and 2 lab hours) - Semester II

$>$ AMT312: Mold Fabrication and Adhesive Bonding of Composite and Metals (2 credits, 1 lecture hour and 2 lab hours) - Semester II

- AMT402: Non Destructive Testing Techniques for Composite Materials (2 credits, 1 lecture hour and 2 lab hours) - Semester II 
In fall 2017, the Engineering and Technology department submitted an application for this certificate program, with all supporting documents, to the NY State Education Department (NYSED), and in mid-November 2017, NYSED approved College to offer this certificate program. The department will begin to offer courses within this certificate program after completing composite laboratory renovation and purchasing all supporting equipment. The contents of this certificate program will be discussed in detail at the ASEE Annual Conference.

\subsection{Computer Aided Design for Additive and Subtractive Manufacturing Certificate}

This certificate program will cover manufacturing systems utilized in the additive and subtractive manufacturing fields. Students will gain hands-on experience developing CAM programs for Haas CNC machines. Rapid prototyping will be covered via 3D Printing systems such as Form 2, Stratasys Fortus 250 MC, 3D Systems ProJet 3600, and Magics 3D printing software. Reverse engineering through the use of 3D scanning will be explored to develop parts using Artec Eva Scanners, Catia, Geomagic, and SolidWorks. At the end of the program, students will have a strong foundation in real world computer-aided design, computer-aided manufacturing, and fabrication techniques. This is a one year certificate program and a total of four practical computer-aided design and additive manufacturing courses ( 8 credits) as listed below will be required to complete this certificate program.

$>$ CDE117: Computer Aided Design with Solidworks, 2 credits, 1 lecture hour \& 3 lab hours - Semester 1

$>$ CDE385: CATIA Fundamentals, 2 credits, 1 lecture hour \& 3 lab hours Semester 1

$>$ CDE375: Computer Graphics for Additive Manufacturing, 2 credits, 1 lecture hour \& 3 lab hours -Semester 2

> CDE487: CATIA for Prismatic Machining and Subtractive Manufacturing, 2 credits, 1 lecture hour \& 3 lab hours -Semester 2

In November 2017, the Engineering and Technology department submitted an application for this certificate program, with all supporting documents, to the NY State Education Department (NYSED), and in January 2018, College recived a letter of approval from NYSED for this certificate program. The department will begin to offer courses within this certificate program after completing laboratory renovation and purchasing all supporting equipment. The contents of this certificate program will be discussed in detail at the ASEE Annual Conference.

\subsection{CNC Machining and manufacturing}

This certificate program will cover manufacturing systems utilized in Computer Numerically Controlled (CNC) manufacturing. Students will gain hands-on experience developing G-code and CAM programs for Haas CNC and Lathe machines. Part inspection will be conducted via traditional gauges and a granite inspection table in addition to precision measuring employing 
a Complex Measuring Machine (CMM) from Aims Metrology and Renishaw. Upon completion of this program, students will have a strong foundation in CNC part development and fabrication techniques. This will be a one year certificate program and a total of four practical courses in computer-aided design, CNC machining and manufacturing (8 credits) will be required to complete this certificate program. In spring 2018, the Engineering and Technology department will submitte an application for this certificate program, with all supporting documents, to the NY State Education Department for their review and approval. .

\subsection{UAV Design and application}

This certificate program provides students with design and hands-on skills in UAV. Students will have the chance to design, build, and fly quadcopter-UAV to serve specific civilian and commercial applications. During the design and building process of the UAV, Students will be familiarized with CAD software and 3D printing technology, and they will learn to equip UAV with basic control units such as IMU. This will be a one year certificate program and a total of four practical courses ( 8 credits) in UAV design, construction and application will be required to complete this certificate program. In spring 2018, the Engineering and Technology department will submitte an application for this certificate program, with all supporting documents, to the NY State Education Department for their review and approval.

\section{Manufacturing Laboratories}

The College's current Title III grant provides necessary support to further develop current laboratories and to create new laboratories providing students with the practical hands-on manufacturing skills they need, and the institution is grateful for this support provided by the US Department of Education. The Engineering and Technology Department is in the process of completing the establishment of five new manufacturing laboratories with state-of-the-art equipment in composite, $\mathrm{CNC}$, 3D additive manufacturing, UAS, and automation. An update on these laboratories and on the supporting equipment will be discussed in detail at the ASEE Annual Conference.

\section{Conclusion}

The manufacturing curriculum committee completed the development process of the Advanced Manufacturing concentration, part of College's existing mechanical engineering technology program. This program will introduce students to the hands-on practical manufacturing skills in CNC programming and machining, Computer-Aided Design and 3D Additive Manufacturing, Composite Manufacturing, and UAV construction and application. The industry advisory members reviewed the contents of this curriculum during College's 3rd annual Manufacturing day on Oct 27, 2017, and the manufacturing curriculum committee and department received commendations for developing a curriculum that embedded all current manufacturing skills. The final version of this curriculum will be introduced to the advisory members during College's tenth annual technology day conference on April 27, 2018. 
Along with the composite design and manufacturing and the $3 \mathrm{D}$ additive and subtractive manufacturing certificate programs which were submitted to the NYSED in fall 2017, and both received approval, the curriculum committee also developing two more manufacturing certificate programs in UAV, and CNC Machining which will be submitted to NYSED in spring 2018. The manufacturing curriculum committee will discuss in detail the development and implementation process for the advanced manufacturing curriculum, the manufacturing certificate programs, and the laboratories at the ASEE Annual Conference.

\section{References}

[1] Rahemi, Hossein, "Ninth Annual Vaughn College Journal of Engineering and Technology", Vaughn College, New York, April 2017.

[2] Rahemi, Hossein, "Tenth Annual Vaughn College Journal of Engineering and Technology", Vaughn College, New York, April 2017.

[3] ABET- Engineering Technology Accreditation Commission "Criteria for Accrediting engineering Technology Programs," 2018-2019 Accreditation Cycle.

[4] Hossein Rahemi and Naveen Seth, "Student Learning Outcomes: An Integrated Continuous Improvement Process for Course and Program Assessment", Latin American and Caribbean Journal of Engineering Education (LACJEE), Vol. 2, No. 2, pp. 54-62, 2008. (C) LACCEI, ISSN 1935-0295. 